\title{
Creating access to land grant resources for multicultural and disadvantaged farmers
}

\author{
Marcia Ostrom ${ }^{a}$ \\ Small Farms Program, Center for Sustaining Agriculture and Natural Resources, Washington State University \\ Bee $\mathrm{Cha}^{\mathrm{b}}$ \\ Small Farms Program, Center for Sustaining Agriculture and Natural Resources, Washington State University \\ Malaquías Flores ${ }^{c}$ \\ Small Farms Program, Center for Sustaining Agriculture and Natural Resources, Washington State University
}

Submitted 11 March 2010 / Accepted 13 April 2010/ Published online 20 August 2010

Copyright (C) 2010 New Leaf Associates, Inc.

\begin{abstract}
The fastest growing demographic sectors of Washington agriculture are Latino, Asian, and women farmers. The majority of these farms are small, with over three-fourths of Latino, Hmong, or women-operated farms having fewer than 50 acres and less than $\$ 50,000$ in sales. Small farms make up 90 percent of all Washington farms, with 35,269 counted in the last census. Unfortunately, most conventional farming education models are not well-suited to farmers with limited access to land, water, and capital, or with limited literacy or limited English proficiency. Meeting the needs of this new generation of farmers will require rethinking many standard approaches to public agricultural research, education, and assistance.
\end{abstract}

\footnotetext{
a corresponding author: 1100 North Western Avenue, Wenatchee, WA 98801 USA; +1 (509) 663-8181 x263; mrostrom@wsu.edu

b 2606 West Pioneer, Kalkus Hall \#317, Puyallup, WA 98371 4998 USA; Bee_Cha@wsu.edu

c 128 North 2nd Street, Room 233, Yakima, WA 98901 USA; mflores@wsu.edu
}

This article examines various alternative formats for reaching diverse producers with sustainable farming education that have been piloted by the Washington State University Small Farms Program, including participatory courses, farmer-to-farmer learning strategies, experiential workshops, audiovisual strategies, and simultaneous translation.

\section{Keywords}

Beginning farmers, farmer-to-farmer, small farms, Hmong farmers, immigrant farmers, Latino farmers, multilingual, participatory, sustainable agriculture, multicultural

\section{Introduction and Background}

In the 2007 Census of Agriculture, 90 percent, or 35,269 , of Washington's farms met the USDA (1998) definition of a small farm, meaning they had total sales of less than $\$ 250,000$ (USDA, 2007). Just as in the country as a whole, immigrant and women farmers are the fastest-growing demographic sector of the state's agriculture. In Washington, the number of Latino, Asian, and women farm operators increased by 43 percent, 36 percent, and 44 percent, respectively, between 2002 and 2007. 
The 2007 Agricultural Census counted 2,605 Latino, 669 Asian, and 8,090 women producers in the state. While there is not a separate census category for them, the authors have identified 88 Hmong-operated farms. The majority of immigrant and women-owned farms are small, with over 75 percent of Latino, Hmong, or women-operated farms having less than 50 acres and under $\$ 50,000$ in sales. While sales may appear low on these farms, our research shows that it can be a critical component of household income (Ostrom, 2005a).

In addition, Washington is home to many refugees, farm workers, farm apprentices, and others who aspire to own their own farms, but are not identified in the Agricultural Census as farmers. For example, 50 Somali and 35 Burundian refugees with agricultural backgrounds in the Seattle area have requested assistance with starting farms. In Central Washington, Latino agriculturists who work on other people's farms can sometimes purchase a few acres of their own to start small, part-time farms. It is also common for freshmarket organic farms in Washington and elsewhere to have one or more farm apprentices or interns studying to become farmers.

This new generation of aspiring farmers is emerging in Washington just as many communities struggle to preserve their farmland and farming infrastructure in the face of reduced farm profitability, intense development pressure, and farmer retirements. The average age of Washington farmers is 57 (USDA, 2007). Unless they inherit farms from their families, most incoming farmers cannot afford to purchase land at going market rates based on the income they can realize from farming. Beyond high land costs, farmers face rising input costs, tightening government regulations, and highly competitive global markets. Thus, as growers retire, farmland in Washington is frequently taken out of production. Over the past 10 years, the state lost 678,606 acres, or 4.3 percent, of its farmland (Stuart, 2008; USDA, 2007). Finding ways to support incoming farmers will be critical to protecting the future vitality of Washington's agriculture and rural communities.
While commodity prices in global markets have generally been depressed and unpredictable, some new opportunities have emerged in local, direct, and specialty markets. Increasingly, entrepreneurial-minded farmers in Washington seek to improve their revenues by orienting their production toward the rising local consumer demand for high-quality, fresh, sustainably produced, and local farm products (Ostrom, 2006; Ostrom \& Jussaume, 2007). Direct-marketing channels in Washington such as farmers' markets have seen rapid growth, increasing from total annual sales of $\$ 5$ million in 1997 to an estimated $\$ 65$ million in 2008 (WSFMA, 2010). During this same period, the total number of markets in the state doubled to 114 (WSFMA, 2010). Similarly, direct sales through farm stands, retailers, institutions, restaurants, community supported agriculture (CSA), and agritourism are also on the rise (Ostrom, 2005b; Ostrom \& Jussaume, 2007).

Unfortunately, most conventional farming research and education approaches have not been well suited for small-scale farmers who raise diversified, specialty crops or livestock, use sustainable or organic farming methods, have limited resources, or employ alternative marketing strategies (GarciaPabon \& Lucht, 2009; Hassanein, 1999; HoltGiménez, 2006; Ostrom, V. Yang, Tadesse, Chang, N. Yang \& Lee, 2002; Ostrom \& Jackson-Smith, 2005; Suvedi, Knight Lapinski \& Campo, 2000; USDA, 1998). Immigrant and refugee farmers may face additional challenges due to limited literacy and English proficiency; limited access to basic resources such as land, water, capital, or transportation; and a lack of familiarity with local growing conditions, regulations, and markets. And while they may be skilled agriculturists, they may lack essential business and environmental riskmanagement skills.

Rethinking standard approaches to public agricultural research, extension, and assistance for this audience is necessary because (1) they usually focus on export-oriented, high-input, industrial-scale commodity production that requires intensive capital investment, and (2) they frequently follow a diffusion-and-adoption approach where new 
science and technologies are developed in university and industry settings and "extended" out to farmers for their adoption. While this model has worked well to spread modern agricultural technologies around the world, it has been criticized for its negative impacts on the environment, crop diversity, and small farmers growing local foods to meet local needs (Altieri, 2002; Chambers, 1983; Dahlberg, 1979; Desmarais, 2007; Holt-Giménez, 2006; Lappe \& Collins, 1977).

In contrast, proponents of sustainable agriculture and food systems have argued that agricultural science should be tailored to local agro-ecosystems and measured against such goals as viable livelihoods for farmers and farm workers, environmental protection, and social equitability (Buttel, 1993; Chambers, 1983, 1994; Kloppenburg, 1991). Beyond the production system, goals for local food security and access are increasingly becoming part of the conversation (Allen, 2004; Hassanein, 2003). In creating alternative food and farming models, a growing body of educators has emphasized the need to value the experience, knowledge, and interests of the farmers themselves as they work within their specific agronomic, ecological, labor, and market contexts (Kloppenburg, 1991; Hassanein, 1999; Gerber, 1992; Chambers, 1983; Francis \& Carter, 2001). More participatory and interactive research and education approaches could allow farmers and university agricultural specialists to exchange ideas in ways that incorporate the farmer's perspective and thus have a greater likelihood of success (Altieri, 2002; Chambers, 1983, 1994; Francis \& Carter, 2001; Gerber, 1992; Hassanein, 1999; Holt-Giménez, 2006; Percy, 2005; Peters, 2002).

From his evaluations of over 1,000 participants in sustainable agriculture education programs, Francis and Carter (2001) showed positive learning gains from replacing lecture and slide-show formats with participatory discussions, on-farm training events and demonstrations, small group discussions, and experiential field learning opportunities. The effectiveness of approaches based on farmer-tofarmer learning and farmer-to-farmer networking for developing and spreading new sustainable farming models has been documented by Hassanein (1999) and Holt-Giménez (2006). Hands-on learning, farmer-to-farmer demonstration, and farmer mentoring have proven to be especially important for new entry immigrant and refugee farmers (for examples see: Rhodes \& Joseph, 2004; ALBA, 2010; Tufts, 2010).

\section{Cultivating Success Immigrant Farmer Program Overview}

For the past eight years, the Washington State University (WSU) Small Farms Program and the University of Idaho (UI) have partnered with a nonprofit farming association, Rural Roots, to develop, offer, and evaluate a collaborative sustainable small farming education program called Cultivating Success. The overall goal of the Cultivating Success program is to foster the longterm success and viability of small-scale farmers in Washington and Oregon through communitybased education.

This collaborative education program was born out of recognition by the partners that beginning, small, minority, women, and other limited-resource farmers, as well as diversified specialty-crop and direct-market farmers, were underserved by the land grant agricultural research and extension programs and the federal farm programs in the two states (USDA, 1998; Ostrom, Jussaume \& Jarosz, 2002). Our goal was to engage small farmer stakeholders in needs assessment and educational program development to ensure the greatest possible relevancy and optimize access to existing public agricultural resources by diverse farmers.

The Cultivating Success curriculum combines participatory classroom learning approaches with experiential, on-farm learning opportunities. Designed to be offered by county extension faculty, the program features farmer-to-farmer discussions led by a variety of local farmer innovators; interactive seminars with local agency, business, and university resource people; small group exercises; hands-on field exercises; interactive visits to established farms and value-added enterprises; and mentoring by experienced, successful farmers who want to share their knowledge. 
From its initial launching in a few pilot counties in 2001, the program has seen steady growth, with nearly 3,000 participants taking courses in 33 counties by 2009. While there is much to consider about this program as a whole, this article is going to focus specifically on our adaptation of the Cultivating Success program for immigrant farming audiences. The following paragraphs outline the basic components of the immigrant farmer program: staff capacity-building, sustainable farming courses with one-on-one follow-up, audiovisual strategies, and "Farm Walks."

\section{Cross-Cultural Capacity Building}

In response to requests for assistance from county Extension faculty and nonprofits, grant funds were initially secured by the WSU Small Farms Program in 2004 to begin reviewing and adapting our Cultivating Success curriculum for Hmong and Latino immigrants. First, bilingual consultants with connections to the target communities were hired to assist with stakeholder listening sessions and interviews to assess educational needs.

From the needs assessment process it became clear that full-time staff members with bilingual and cross-cultural skills would be needed in order to design and offer effective sustainable farming education for immigrant farmers. Accordingly, over the next five years the WSU Small Farms Program sought and received additional grant funds to enable staff capacity-building. This included hiring full-time bilingual specialists in Hmong and Spanish (authors Cha and Flores, respectively) and organizing cultural competency training for all program staff.

With assistance from Heifer International and the Highlander Center, we also organized an intensive interpreter ${ }^{1}$ training for staff members and area agricultural professionals with bilingual skills,

${ }^{1}$ Interpretation refers to transferring a message from a source language into a different language in a linguistically, emotionally, and culturally equivalent manner using oral or sign language. In contrast, translation refers to transferring equivalent meanings from one language to another working from text to text. including training in simultaneous and consecutive interpretation ${ }^{2}$ techniques in the fall of 2008. This was a two-day, intensive, hands-on learning experience in cross-cultural, cross-language interpretation; the creation of inclusive multilingual spaces; and the usage of simultaneous translation equipment. The goal was to build a "bank" of skilled interpreters who could be called upon when needed to assist with educational events.

\section{Sustainable Farming Courses}

\section{Whole Farm Management and Planning}

For English speakers, this weekly evening or weekend course takes place during the winter offseason and ideally is led by trained county Extension educators with an interdisciplinary, holistic approach to farming systems, a strong knowledge of the local community, and an understanding of participatory adult educational techniques. The goal of our curriculum is to introduce participants to ecologically based production practices, including integrated soil and pest management, pasture-based livestock systems, and organic certification requirements in a whole farm planning context. The participants develop the skills needed to evaluate the full range of production and marketing options given their financial, labor, and natural resources, their location, climate, soils, proximity to markets, and other social, economic, and environmental goals. Classroom modules are supplemented by hands-on homework assignments, field exercises, and onfarm seminars held at exemplary local farms. The capstone assignment is the development and presentation of a Whole Farm Plan that integrates personal goals with decisions about production, financing, labor, marketing, and natural resource management.

\footnotetext{
2 In simultaneous interpretation, the interpreter communicates the message in the target language as rapidly as possible while the source language is spoken continuously. Microphones and headsets are commonly utilized, although the interpreter can also speak softly to a small group without audio equipment. In consecutive interpretation, the interpreter speaks in segments after the source-language speaker has paused.
} 
While this course has proven popular with a general small-farm audience, the English version relies to some extent on reading and writing assignments. This approach had to be completely reassessed for Hmong and Latino farmers due to literacy limitations. For these audiences, Cha and Flores adapted the course to rely more on oral presentations, hands-on demonstrations, and audiovisual aids, such as graphic slides and video and audio recordings. From initial needs assessments we learned that the Hmong written language is seldom used, so printed materials were not translated into Hmong. We did translate the course curriculum and other printed resources into Spanish. We also tested the idea of offering individual course topics as standalone "workshops" to see if that format worked better than an extended course offering. Also, we organized farmer study groups that meet outside the course time to address topics like pest management in greater depth.

\section{Business Planning, Entrepreneurship, and Marketing}

This course was originally designed as a sequel to the above course for beginning farmers, as well as those who were already farming but who wanted to assess their sustainability or make a transition to new crops or markets. This course is typically cotaught by a county-based Extension educator and, where needed, a business expert such as a counselor from the state Small Business Development Centers or another trained business expert. Course formats piloted for English speakers included weekly evening courses, weekly Saturday morning courses, and four-day intensive workshops.

We use a similar format of interactive classroom learning, combined with hands-on exercises, and field visits. Farmer mentors and other guest experts are drawn from the local area to cover key concepts in business management and entrepreneurship. For example, participants have an opportunity to learn directly from bankers about financing issues; from marketing specialists about processing, packaging, promoting, and selling; from attorneys about legal issues; from income tax specialists about tax filing; from government agencies about farm assistance programs; and from farm accountants about effective bookkeeping systems and budgeting. Local small farmer mentors share their business plans, record-keeping, and marketing systems with the class. Weekly course assignments focus on completing specific pieces of the farm business plan. The final assignment is to complete and orally present a farm business plan.

As will be detailed in the results, this has been a difficult course to adapt for immigrant farmer audiences, largely due to the complexity of the written and financial materials. Our approach was to revise the curriculum by shortening and simplifying the concepts presented as much as possible. This revised curriculum was translated into Spanish. For the Hmong audience, however, the topics were orally translated by the instructor during class. At the request of the Hmong farmers, the forms and handouts remained in English so that younger family members who have been educated in American schools could read them. Farmer-to-farmer learning strategies, hands-on workshops, and field visits were employed with simultaneous and consecutive interpretation where needed.

\section{Follow-up One-on-One Consultation}

For the multilingual audiences, we budgeted instructor time to follow group learning activities with extensive one-on-one coaching and assistance to design an individualized business plan and a practical record-keeping system. Individual consultations with the instructor took place as farm visits or at the Extension office. We tried as much as possible to involve all family members in the business-planning process to ensure their buy-in and to gain the benefit of the literacy and language skills of the younger generation.

A new idea employed with two Latino businessplanning courses was to pair Spanish-speaking college business students with a farm couple. The students helped the farmers write their farm business plans as part of their class assignment, providing the farmers with extensive individualized attention and the students with real-life business case studies. 


\section{Radio and Audio CD}

We worked with the Washington State Department of Agriculture (WSDA) to obtain funds to write and record 10 thirty-minute radio scripts in Spanish on key instructional topics from the Cultivating Success courses. The format was modeled on talkshow interviews and covered such topics as direct marketing, licensing and regulations, food safety, financing options, crop insurance, pesticide regulations, and federal conservation programs. The topics were first broadcast as monthly radio shows on the KDNA Spanish-language radio channel for central Washington. The recordings were then made into CDs and offered as a free, 5$\mathrm{CD}$ audio booklet to interested beginning and established farmers. Because radio broadcasts and audio CDs tend to be readily accessible and popular with Latino agriculturists for use while driving, we hoped that these media might help overcome the time barriers to attending workshops or classes in person.

\section{Hmong Youth Video Project}

In an interesting offshoot of the Hmong farmer education program, Cha has involved Hmong farm youth from the Seattle area in videotaping and producing educational films about Hmong cultural traditions and farming practices. The goal was for the Hmong youth to learn how to create educational videos in Hmong to use with the different Cultivating Success course topics while gaining new practical skills and knowledge about their communities. With assistance from a nonprofit Seattle film studio, 911 Media Arts Center, and supplemental grants from the local conservation district, Cha recruited a dozen Hmong farm youth to attend 12 weekly courses to learn how to shoot and edit videos. The instructors at the film studio taught the group of youth and four Extension staff mentors how to structure film projects from preproduction planning through film photography and editing.

\section{Bilingual On-Farm Workshops}

Each year our WSU Small Farms Program offers a "Farm Walk" series designed to facilitate experiential, farmer-to-farmer learning on the most innovative and advanced organic farms in the state.
The series is organized in partnership with the Tilth Producers Association of Washington to ensure the strongest possible grower participation in program design, implementation, and evaluation. In its sixth year, this program brings farmers and agricultural scientists together on farms around the state to study the techniques used by advanced organic farmers and to discuss challenges and practical solutions.

The walks provide an opportunity to share the unique technical expertise of established growers with current and future farmers through discussion and demonstration sessions. The goal is for attendees to learn new production and marketing strategies that can improve environmental and economic outcomes and try them out on their own farms. Held throughout the growing season in geographically disperse areas of the state, a study theme that highlights the farm's unique attributes is selected ahead of time and a comprehensive resource manual is prepared. During the 2007 through 2009 seasons four Farm Walks were designed and promoted specifically for bilingual farmer audiences. In two cases, the farmers themselves were Spanish speakers, so presentations were made in Spanish with interpretation back to English provided by our staff. In the other two cases, although the farmers were native Hmong and Spanish speakers, they wanted to make their original presentations in English with interpretation back to Hmong and Spanish provided by Cha and Flores. In all cases, only two languages were offered at a time: either Spanish/English or Hmong/English.

\section{Applied Research Methods}

Data was gathered for this case study of the Cultivating Success Immigrant Farmer Program in a variety of ways, including needs assessments conducted through listening sessions, surveys, and interviews; program records; and formal evaluations. In addition, as program organizers and instructors we draw on our own experiences, observations, and reflections. We were not detached researchers, but rather committed participants and co-learners aspiring to employ participatory research and evaluation methods to 
the extent possible (see McGuire, 1987; Fals-Borda \& Rahman, 1991). We occupied positions of power relative to the program participants which certainly affected the dynamics of the learning environment and the feedback we received. We fully recognize that our own interests and biases have shaped our research process, our interpretation of the evaluation findings, and the conclusions we have drawn.

Rural Roots, Inc. (2007a, 2008) was hired as an outside professional evaluator to implement formal evaluations of all Cultivating Success programs. Evaluations were conducted at the end of each course or learning activity and, in addition, past participants were contacted one to three years after their participation to assess longer-term outcomes. As will be discussed, the standard Cultivating Success evaluation tools and processes had to be adapted in a variety of challenging ways to serve a multicultural audience.

\section{Needs Analysis}

Our WSU Small Farms Program conducted a statewide survey of small farm operators in Washington to determine their research and education needs as accurately as possible at the establishment of the program. In 2002, we drew a statewide random sample of all farmers from the Washington Agricultural Statistics Service (WASS) farm list and sent them mail surveys asking a variety of questions about their farm characteristics, farming and marketing practices, and research and extension priorities (Ostrom, et al., 2002). With a response rate of nearly 50 percent, this survey had 1,600 responses that turned out to be quite representative of the farm categories in the state and could be sorted by farm size. In another approach to reach small growers, we built our own list of 1,743 small farms in Washington and Idaho based on existing databases and drew a sample from these small farms specifically (Rural Roots, 2007b). This mail survey had a response rate of 42 percent.

While these surveys did have a few respondents who identified themselves as Hispanic or Asian, we realized that a mail survey was an inadequate method for reaching new immigrants and refugees or those with limited English or literacy. Instead of relying on survey results for this audience, we organized targeted listening sessions and personal interviews using bilingual facilitators.

The first task was to locate and identify Hmong and Latino farmers since they did not show up on any preexisting farmer lists and most were not counted in the 2002 Agricultural Census. Because they market their products almost exclusively at farmers markets, the Hmong farmers were identified largely through the markets, as well as through extended family networks. Latino farmers were first identified through a variety of outreach methods, beginning with informational interviews with church staff, soccer associations, and health clinics in the target region of Central Washington. Outreach was also conducted with farm workers to identify those who may have started their own farms on the side or may aspire to start their own farms. The pesticide certification clinics required by the Washington State Department of Agriculture for all farm workers who handle pesticides proved to be a useful venue for reaching farm workers interested in farm ownership. Through these methods a database of 88 Hmong operated farms (associated with 280 different adult farmers) and 289 Latino-operated farms was constructed. Because they farm in extended family networks, most Hmong farms have multiple adults associated with them.

Using telephone recruiting from the farmer database, three listening sessions were held with Hmong farmers in the Seattle area in 2004 and one in Spokane in 2006. These listening sessions, held in Hmong, drew from 15 to 20 participants each and provided an opportunity to ask participants about their farming and educational interests. Later, Bee Cha also conducted informal personal interviews with all the Hmong farmers he could find by visiting each farmers market in the Puget Sound area in 2006. Working with the Center for Latino Farmers in Yakima to recruit participants, again by telephone, three listening sessions with Latino farmers were held by Malaquías Flores in Central Washington in 2005. Another 285 Latino 
farmers were surveyed about their needs by Malaquías Flores at this time using farm visits to conduct oral interviews.

\section{Post-Activity Evaluations}

With assistance from Rural Roots as the evaluator and our Cultivating Success management team, written evaluation tools were developed for use at the end of courses and other activities. Over 1050 individual written evaluations of courses and Farm Walk activities have been collected from participants. Wherever relevant, the written evaluations were translated into Spanish. However, it is clear that traditional written forms of evaluation hold limited value for most of the Hmong speakers and many of the Spanish speakers.

For this reason, we experimented with methods of conducting post-activity evaluations that did not rely on written forms. From consulting with Heifer International, we learned several techniques for participatory evaluation such as using hand raising, stepping forward or back, or moving to various stations to indicate different responses to the evaluation questions posed. At the end of courses for Latino farmers we also experimented with evaluation questions designed as focus group interviews led by a Spanish-speaker other than the course instructor. Finally, all Cultivating Success instructors are encouraged to check-in with their students regularly throughout a course to make sure that student goals are being met.

Most recently in 2009 we tested a new automated, audience response "clicker" system with Latino farmer audiences. Each participant was issued a small electronic clicker like a television remote control device with numbers on it. An oral question was posed and the meanings of the response categories from 1-5 were explained. Each time a question was asked, the respondents anonymously selected their answer category with a click. The different responses were automatically aggregated on a laptop and projected graphically on a screen for audience review, as well as read out loud. Participants really seemed to enjoy this process and immediate feedback, in contrast to traditional written evaluations.

\section{Past Participant Evaluation}

English-speaking past Cultivating Success Course participants with valid addresses were surveyed in the winter of 2006 by mail survey (Rural Roots 2007a). In addition, outside bilingual evaluators were hired to conduct oral interviews with past Hmong farmer and Latino farmer participants.

Additional surveys of past Hmong and Latino program participants were conducted using bilingual outside evaluators hired by Rural Roots and oral interviews in Hmong and Spanish in the winter of 2009-2010. English-speaking past students were contacted and provided with a choice of mail or online surveys.

\section{Results and Discussion}

In this discussion of the impacts and outcomes of our Cultivating Success program for immigrant farmers, we report on the findings from the evaluations that were conducted at the end of each individual educational activity, as well as interviews that were held with past participants one to five years after participating in a program. This discussion also incorporates the records, observations, and experiences of the authors who organized and offered these programs. Further, we reflect on the relative efficacy of the different evaluation techniques that we tested for their relevance in cross-cultural and limited literacy settings.

\section{Capacity Building}

Our experience made it clear that engaging diverse groups of new farmers would require going well beyond providing translation of existing written materials or arranging interpretation for existing educational programs. As experienced in attempts to engage multilingual audiences around the country, building attendance at educational events without prior personal contact or a personal relationship with an organizer is difficult. For example, extension educators, non-profits, and government agency personnel in Washington had been trying to engage Hmong refugees in agricultural programs for years with generally low participation rates. 
First, personal relationships of trust with the educators had to be developed in order to build meaningful program participation. For us, this required hiring staff possessing both strong bilingual qualifications in the target languages as well as strong cross-cultural skill sets. It also required a significant time investment and a willingness to be physically present to build relationships in the target communities. We observed that such relationship building can be very difficult to accomplish within the time span of a single grant proposal. We were fortunate to be able to acquire continuous grant funding for our immigrant farmer program over a period of five years so that we could avoid staff turnover and establish and maintain personal relationships with the farmers and immigrant communities. It was through these relationships that farmers and aspiring farmers gained familiarity with our educational programs and became interested and comfortable participating.

We also found that it was important to provide close collegial support and professional development opportunities for bilingual educators, as well as cultural competency training for all program staff. The job of a bilingual agricultural educator can become overwhelming because once these specialists become known and trusted in an immigrant farmer community the demands on their time can be extreme. Other government agricultural agencies may soon begin to recognize their value and rely on them as a key link to the farmers for their assistance programs. The farmers themselves may begin to see these educators as their primary support system for solving all of the problems and crises encountered in adjusting to life in a new country and culture.

Offering educational programs that better equipped all of our Small Farms Program staff and other Extension and non-profit personnel to assist with multicultural programming helped to spread the responsibilities beyond the two bilingual educators. Participant evaluations of the diversity workshop and the intensive interpreter training held for staff and other area agricultural professionals were extremely positive. Around 70 agency professionals, educators, and non-profit service providers participated in what we called a "Multicultural Farming Roundtable" held on the border of Central Washington and Oregon in the fall of 2008. In the evaluations collected, 86 percent of respondents said they would make changes in their programs to support multicultural constituents and every respondent reported having made valuable new connections at this event. The aspects of the workshop most appreciated by participants were the presentations of their stories by immigrant farmers, the value of the networking opportunities provided, the new information about available resources, and the sector diversity of the conference participants. It appeared that many public sector service providers were eager to serve diverse farmer audiences, but lacked the skills and knowledge of how to get started. There were widespread requests for follow-up learning activities of a similar type.

Perhaps the most significant professional development activity was the intensive interpreter training for bilingual agricultural professionals that we coorganized with Heifer International and a national trainer from the Highlander Center in Tennessee. On 100 percent of the evaluations from the agricultural interpreter training workshop respondents indicated that they had gained new knowledge of how to create multilingual spaces that would impact their future work.

The important lesson here was that just because a person possesses bilingual skills, they do not "automatically" understand interpreting techniques or how to use the simultaneous interpretation equipment. Interpreting by itself is a highly skilled profession that can take years to learn to perform well. It was essential that we provided our educators with at least some introduction to the basic skill sets needed to accomplish this work. Already, in the past two years, trained interpreters from our workshop have offered simultaneous interpretation for bilingual farmers at important workshops, small farms conferences, and Farm Walks in the state, making it possible for hundreds of multilingual agriculturists to participate in these events. In some cases, we have turned the tables 
(and the power balance) and used the simultaneous interpretation equipment to make it possible for English speakers to attend presentations held in Spanish or Hmong.

\section{Needs Assessments}

Our surveys, evaluations, and focus groups with English-speaking small farm operators and beginning farmers in Washington and Idaho made it overwhelmingly clear that farmers prefer to learn from other farmers in realistic, on-farm settings. In our 2006 survey of 412 small-scale producers (Rural Roots, 2007b) around half of the respondents felt that the majority of new farmer education should occur on a farm. On-farm activities were the most preferred educational formats for both new and experienced farmers. Eighty-seven percent of respondents thought farmer-to-farmer learning would be useful or extremely useful. About 72 percent of respondents indicated they would be likely to participate in such opportunities.

Results from initial listening sessions and evaluations held specifically with Hmong and Latino farmers confirm the same preference for on-farm and hands-on learning activities. However, our initial needs assessments also identified unique characteristics and needs among these groups of farmers. Flores found that among the Latino farmers interviewed:

- 90 percent say they prefer to learn in Spanish

- Four our of five are from rural areas of Mexico

- Most are first generation immigrants

- 85 percent already owned their farmland (average size: 30 acres)

- The most common crops were fruits, followed by vegetables

- Most used wholesale rather than direct or value-added markets

- Strong interest in testing new marketing strategies and cooperatives

- Four out of five farmers had off-farm jobs

- Average education was sixth grade
Working with the Hmong community, Cha identified a total of 80 Hmong farm operations in the Seattle region and eight in the Spokane region. These farms are all operated by extended families so each farm has multiple farmers associated with it. Initial needs assessments with Hmong farm families revealed the following information:

- Most prefer to learn and receive information orally in Hmong

- Interested in audiovisual educational approaches

- Most have little or no formal education

- Traditionally, education occurred through oral and visual storytelling

- Most families have incomes below the poverty level

- Nearly all farmers rent rather than own their land

- Access to water, land, and transportation is extremely limited and insecure

- Flowers, followed by vegetables are most common crops

- Farmers markets are the primary market outlet

- Many have difficulty accessing the better farmers markets and feel excluded

- May have communication challenges with market managers

- Use very low-input farming systems

- Use hand labor primarily

- Rely on extended family members as labor source

- Want more information about mechanization options, especially equipment selection and repair

- Concepts of marketing, record keeping, budgeting, planning, pricing, etc. are unfamiliar

- Have little familiarity with Extension or federal agricultural assistance programs

- Social relationships are structured by strong kinship networks

Many of the marketing and business management needs we identified were similar to those identified in a University of Minnesota study of Hmong 
specialty crop growers in the Minneapolis area

(Olson, et al., 2003).

\section{Participation in Courses and Workshops}

\section{Hmong Programs}

Over the five years of this project, 280 different Hmong refugees participated in our pilot educational programs. Another 406 have viewed our Hmong videos at screenings held at the Hmong New Year Celebrations in Seattle and Spokane. A smaller subset of 35 farmers participated in a course series. In addition to taking advantage of the Hmong New Year gathering, program promotion was based on telephone calls by Cha using our farmer database and by word of mouth.

To the Hmong farmers, the value of attending an ongoing course or participating in an extended educational program was not immediately obvious. They preferred stand-alone workshops, especially workshops with an obvious and immediate benefit, such as the opportunity to receive assistance with repairing equipment at a tractor repair workshop or the opportunity to take home new row covers from a pest-management workshop. The workshops most well attended by the Hmong farmers have been hands-on sign-making and business-card workshops where they could take home new farm banners, produce labels, and business cards.

In the needs assessment and evaluation process, when they were questioned about the overall value of educational programs in general or in the abstract, the Hmong respondents were fairly critical or seemingly uninterested. However, when asked about specific workshops or the assistance provided by Bee Cha specifically, interview comments expressed strong appreciation. Also, when asked if they would recommend the programs offered by the WSU Small Farms Program to others, over 90 percent responded that they were "very likely" to do so (Rural Roots, 2010).

Interestingly, based on interview responses (Rural Roots, 2010) and the observations and experiences of Cha, the Hmong farmers were not very positive about the idea of farmer-to-farmer networking and knowledge-sharing. For example, in response to the translated interview question, "To what extent have you networked with other course or workshop participants?" all of the Hmong respondents selected the multiple choice answer of "not at all." The qualitative comments were mixed, with one farmer stating (after translation), "It's good to learn from each other, other farmers, and see other's farms and maybe learn something to help yourself." In contrast, another respondent noted, "I would like to share my knowledge but other Hmong don't want to share. We cannot network." Despite the comments on the evaluations, one outgrowth of the Hmong programming by Bee Cha has been the development of a "Hmong Farmer Association." This association, which loosely includes all of the 80 Hmong farm operations in the Puget Sound area, has served as a key decision-making entity, fund-raising mechanism, and distributor of disaster relief in times of community crisis, such as in two recent incidents of heavy winter flooding. Thus, while the importance of farmer-to-farmer networking may not have been directly acknowledged in the evaluations, our observations show that these relationships do hold at least some significance.

Another interesting outgrowth of the Seattle Hmong courses was that Somali refugees found out about them and asked if they could also attend. By the end of 2009, we had 40 Somali participants taking the Hmong course by using a translator. We were also approached by a group of Burundi farmers who did not want to take a course but wanted help starting a cooperative. Bee Cha has continued to do follow-up consultations with these groups of refugees.

\section{Latino Programs}

Participation levels in Latino farmer education programs have been high. Again, in addition to taking advantage of preexisting events, the most successful program promotions have taken place with telephone recruitment from our farmer database or by word of mouth. In central Washington, 151 Latino farmers participated in the whole farm and business planning courses offered by Dr. Malaquías Flores. An additional 46 Latino agricul- 
turists participated in the courses we held in partnership with bilingual instructors from Wenatchee Valley College. Finally, over 3,000 Latino farmers and farm workers have participated in one-time workshops, Farm Walks, and conference presentations. As a follow-up to group educational activities, Dr. Flores has assisted more than 380 farmers individually with developing farm plans and accessing USDA programs and services. Another workgroup of eight Latino farmers has continued meeting regularly with WSU specialists to learn about Integrated Pest Management techniques for orchards.

In contrast to the Hmong farmers, evaluations and needs assessments with Latino farmers show an overall favorable attitude toward the general concept of education. When interviewed or questioned in listening sessions, Latino farmers expressed uniform interest in having access to more educational opportunities. For the Latino farmers, with both the Whole Farm Planning course and the business planning courses, the evaluation process showed that one of the most significant skills participants developed was the capacity to identify emerging market trends and to adapt their enterprises accordingly. This program was designed to help participants learn how to actively seek out information. For example, over 64 percent of business-course participants said that their knowledge of marketing options had greatly increased, and 68 percent said they increased their awareness of available agency resources. One translated quote stated, "I became more businessminded, connected to local resources, and learned how to market."

The Latino farmers had particularly favorable evaluations regarding the knowledge they gained from the bilingual Farm Walks held on Latinooperated farms. For example, after one such daylong event held on a fresh market organic vegetable farm (presented in Spanish and translated to English), Latino participants in the following percentages said they either somewhat or greatly increased their knowledge in the following topic areas: farm profitability (69\%), soil fertility $(96 \%)$, composting (42\%), alternative pest management $(62 \%)$ and marketing (58\%).

Latino farmers also stated that they valued farmerto-farmer learning and networking opportunities. In the pest management workgroup, 70 percent of respondents stated that the information obtained from the work group was "very important" to their farm decision-making on pest management. Finally, extensive comments elicited through past student evaluations emphasize that the one-on-one consultations with the instructor were the most highly valued aspects of the program.

\section{Radio and Audio CDs}

The audio CDs and radio versions of our Cultivating Success course topics developed in partnership with the state Department of Agriculture have proven to be in high demand. To date, more than $650 \mathrm{CD}$ sets have been distributed. More funding is being sought to create and distribute additional copies.

Monthly radio broadcasts of each topic by radio station KDNA in Yakima (La Voz del Campesino at 97.1 FM) were continued over a year and were estimated to have reached around 25,000 radio listeners. KDNA has some degree of reception as far away as Wenatchee. A Spanish-language radio station in the Mount Vernon area (KSVR 91.7 FM) has also inquired about broadcasting all of the CD topic modules. We have not figured out how to evaluate the learning gains from radio programs.

\section{Hmong Youth Video Project}

Learning and passing on information in Hmong culture is traditionally done orally through folk stories and visually through the art of story cloths. While the course style of teaching with regular weekly meeting times has engaged some participants, our needs assessments and participation rates show that many Hmong may not view this as a valuable format. Work schedules, transportation, literacy rates, and learning styles presented additional barriers. Cha observed, however, that many Hmong farm youth have access to DVD players and were very interested in media technologies. In an effort to address the obstacles to classroom 
learning, he organized the Hmong Youth Video project as described previously in the "Cultivating Success Overview" section. As a result of the training they received in this project, Hmong farm youth have now formed a "Hmong Video Club" and have begun actively making videotapes of onfarm, educational workshops on sustainable farming and marketing practices and translating them into Hmong. Around $600 \mathrm{Hmong}$ viewed the first videos at screenings held at the Hmong New Year celebrations in Spokane and Seattle in 2008 and 2009.

While these projects are still in a developmental phase regarding their ability to spread new knowledge about farming and business practices, their value as a participatory learning tool to spur interest Hmong youth in learning about their community, their culture, and agriculture is readily apparent in the videos produced. The project has also assisted these youth in developing marketable skills. Two other organizations, including the Washington Sate Department of Agriculture, have now contracted with the trained Hmong youth to produce videos for them. As noted by Howard Rheingold (2008) in a recently published paper, participatory media education can encourage civic engagement by youth, enabling them to develop their own public voice rather than simply being passive consumers of media. This kind of media project might be expected to hold even more significance for youth from refugee families struggling to makes sense of cultural differences.

\section{Assessing Overall Significance}

In summary, the most significant overall outcomes and impacts that we were able to document and report from our educational activities are listed below. These results are based on follow-up surveys and instructor records.

- Over 280 Hmong farmers participated in WSU educational programs for the first time.

- Ten Hmong farm youth were trained in film-making and editing and have produced educational agricultural videos in English, Hmong, and Spanish.
- Over 600 Hmong refugees viewed the agricultural videos produced by WSU Hmong Youth film makers.

- Over 40 Somali refugees completed our semester-long WSU sustainable farming class designed for Hmong refugees by using an interpreter.

- New minority farmers began participating in USDA farm programs:

o 25 Latino farmers obtained EQIP contracts.

o 55 Latino farmers obtained FSA loans.

o 2 Latino farmers obtained Farm Credit Service loans.

o 2 Latino farmers received organic certification and 8 applied for organic certification.

o 15 new Latino farms were started.

o Two Hmong farms received organic certification.

o One Hmong farm received an NRCS contract.

o One Hmong farm received an FSA loan.

- 100 new Latino farmers and 78 new Hmong farmers participated in the U.S. Census of Agriculture for the first time

- Four new Hmong farms were purchased and 12 new farms were rented.

- A new Burundian farmer cooperative and two Latino farmer cooperatives were established.

- A new Hmong Farmer Association of 80 farmers was formed and it assembled and distributed disaster relief to both 2006 and 2009 Hmong farmer flood victims.

Thus it is clear that our work over the past five years has had some positive outcomes for new, multicultural farmers. We feel that these records are accurate because we can verify them. The accuracy of our evaluation data is less clear. While the Hmong farmers seemed to feel comfortable providing feedback that was critical once they agreed to participate in an evaluation interview, it was difficult to get them to participate in the first place. We found that if the farmers did not previously know the evaluator who contacted 
them, they were unlikely to agree to the interview. We had assumed that hiring an evaluator from outside the community would be important for obtaining objective responses; however, without a prior personal relationship the evaluations could not be conducted. The first time we tried to do evaluations by using a Hmong evaluator from another state, only four farmers agreed to participate. The second time we attempted to conduct evaluation interviews, we decided to hire a bilingual evaluator from within the community to improve participation rates. Even so, we had to work very hard to get a 50 percent participation rate. It seems that if farmers were unenthusiastic about our educational programs or had a criticism they were less likely to agree to do an interview.

We had a different experience with the Latino farmers, who seemed very willing to participate in evaluation interviews regardless of whether they had a personal connection to the evaluator. We suspect that the Latino farmers may have given overly "positive" responses to their evaluation questions because, in comparison with the English and Hmong-speaking farmers, their responses were always more favorable, whether we used written evaluations, mechanical clickers, or oral interviews. Indeed, it was very difficult to get the Latino farmers to ever say anything negative. This may represent a cultural difference reflecting norms regarding "politeness," or it may simply reflect a greater appreciation of the chance to pursue educational opportunities. In both groups, farmer willingness to participate in the evaluation interviews and their opinions about our programs were strongly linked to their perceptions of Malaquías Flores and Bee Cha, whom the farmers saw as synonymous with the program. We still need to do further research to better understand these evaluation response patterns across different cultures.

\section{Conclusions}

Building a team with strong cross-cultural and bilingual skills and knowledge of the target communities proved essential to ensuring that educational approaches and priorities were developed based on accurate and ongoing needs assessments and were piloted with strong participation from target groups. It has taken time, but after refining our efforts our team has become increasingly skilled at creating comfortable and welcoming multicultural and multilingual learning environments. The relationships of trust formed between the project leaders and the farmers provided a participatory environment for guiding program development.

The most important lesson we learned was that establishing personal relationships with the target farmers was of fundamental importance, but it was time- and labor-intensive. It was also critical to recognize and address language and literacy barriers early on in developing relationships in these communities. We found that oral communication worked better than written communication. Interpreters could help make university program content and agricultural specialists accessible once personal relationships were established between the farmers and the program organizers. Without the prior personal connections, however, immigrant farmers were unlikely to feel comfortable attending events designed primarily for English speakers, even if interpretation was available. Finally, we learned about the need to constantly remain adaptable, patient, and flexible, because we still had so much to learn with each new approach we tried. At first, it was difficult to even locate the farmers. Next, it took a long time to build the relationships needed to encourage participation. Then, participation was never guaranteed unless the program itself was viewed as relevant.

From our experience, useful areas for future research would include further study of the most accurate evaluation techniques to use in crosscultural settings. As discussed above, gathering objective feedback from farmer participants was challenging. Another area meriting further attention is the potential funding mechanisms available for this kind of program, where the clients cannot afford to pay for services on a fee basis. It is a significant challenge to fund ongoing, longterm programs using short-term grant funding cycles. While we were able to raise several million dollars to support this program over five years by 
combining multiple grants, we worry about what will happen if the grant sources run out. The time required to build staff capacity and relationships with the target communities do not fit within the annual funding cycles of many grant programs. Indeed, the critical importance of long-term relationship building calls into question the whole idea of developing outreach programs for multicultural farmers based on short-term grants. For example, the USDA Risk Management Agency is an increasingly important funder of outreach programs targeting limited-resource, minority, and socially disadvantaged farmers. The agency has done a commendable job of catalyzing innovative new programs around the country. However, their partnership grants could be far more effective if they were awarded for projects extending more than one year at a time.

In summary, more reviews of immigrant farmer programs across the country are needed to help understand how they are being funded and the effectiveness of the various delivery options available. More policy research is needed on the impacts of current federal policies on these programs and recommendations for changes. For example, it might not be advisable for all of the federal funding for immigrant and beginning farmer programs to be allocated through shortterm competitive grants programs. Perhaps funds could be better targeted toward building ongoing and lasting capacity through improvements to established public agricultural institutions such as Extension and other agencies with a long-term presence in target regions or by supporting longstanding nonprofits with a track record of serving multicultural and small farm audiences. Federal formula funding like that formerly allocated through the Smith-Lever Act Small and Part-time Farmer Program is a good example of targeted funding that provided small but stable funding for small farmer education through public agricultural institutions in each state.

The gains made by our program suggest that with the right incentives and training, public land grant resources can be better utilized to serve the incoming generation of multicultural farmers. It would also be useful to design and fund more meaningful cultural competency and diversitybuilding activities for public agricultural service providers and educators across the country. We found a strong interest in this kind of education among our colleagues, and small investments in this area might have a large impact in terms of capacity building and program effectiveness.

\section{Acknowledgements}

We wish to express appreciation to our entire Cultivating Success Management Collaborative (www.cultivatingsuccess.org), including Cinda Williams and Amanda Snyder at the University of Idaho, Colette DePhelps at Rural Roots, Doug Collins and Cathy Perillo at WSU, Dianne Green of Greentree Naturals, and Lora Lea Misterly of Quillisascut Farm.

We would also like to acknowledge the following programs of the United States Department of Agriculture (USDA) for their generous sponsorship of our Cultivating Success Program for Immigrant Farmers: Sustainable Agriculture Research and Education (SARE), Outreach and Assistance to Socially Disadvantaged Farmers and Ranchers (OASDFR), Risk Management Agency (RMA) Research Partnership, Beginning Farmer and Rancher Development Program (BFRDP), and Financial Services Agency (FSA). We would also like to thank the King Conservation District and the King County Agriculture Department or their support of our Hmong Farmer Program, and the Small Farm Direct Marketing Program at the Washington State Department of Agriculture for their ongoing partnership in our immigrant farmer outreach efforts.

\section{Disclosure}

In the interest of full disclosure, the authors note that they are employed by the Small Farms Program at WSU, a founding partner in the Cultivating Success program.

\section{References}

Agriculture and Land-Based Training Association (ALBA). (2010). Salinas, CA. Retrieved from http://www.albafarmers.org/index.html 
Allen, P. (2004). Together at the table: Sustainability and sustenance in the American agrifood system. University Park, PA: Pennsylvania State University Press.

Altieri, M. (2002). Agroecology: The science of natural resource management for poor farmers in marginal environments. Agriculture, Ecosystems and Environment, 93, 1-24.

Buttel, F. H. (1993). The sociology of agricultural sustainability: Some observations on the future of sustainable agriculture. Agriculture, Ecosystems and Environment, 46, 175-186.

Chambers, R. (1983). Rural development: Putting the last first. New York: Wiley \& Sons.

Chambers, R. (1994). The origins and practice of participatory rural appraisal. World Development, 22(7), 953-969.

Dahlberg, K. (1979). Beyond the green revolution: The ecology and politics of global agricultural development. New York: Plenum Press.

Desmarais, A. (2007). La Via Campesina: Globalization and the power of peasants. Ann Arbor, MI: University of Michigan Press.

Fals-Borda, O., \& Rahman, M. A. (1991). Action and knowledge: Breaking the monopoly with participatory actionresearch. New York: The Apex Press.

Francis, C. A., \& Carter, H. C. (2001). Participatory education for sustainable agriculture: Everyone a teacher, everyone a learner. Journal of Sustainable Agriculture, 18(1), 71-83.

Garcia-Pabon, J., \& Lucht, J. (2009). Latino farmers in Missouri: Risks, services, and implications for Extension. Journal of Extension, 47(4), 1-7.

Gerber, J. (1992). Farmer participation in research: A model for adaptive research and education. American Journal of Alternative Agriculture, 7(3), 118121.

Hassenein, N. (1999). Changing the way America farms: Knowledge and community in the sustainable agriculture movement. Lincoln, NE: University of Nebraska Press.

Hassenein, N. (2003). Practicing food democracy: A pragmatic politics of transformation. Journal of Rural Studies, 19, 77-86.

Holt-Giménez, E. (2006). Campesino a campesino: Voices from Latin America's farmer to farmer movement for sustainable agriculture. San Francisco: Food First Books.

Kloppenburg, J. R. (1991). Social theory and the $\mathrm{de} /$ reconstruction of agricultural science: Local knowledge for an alternative agriculture. Rural Sociology, 56(4), 519-548.

Lappe F., \& Collins. J. (1977). Food first: Beyond the myth of scarcity. Toronto: Houghton Mifflin Co.

McGuire, P. (1987). Doing participatory research. Amherst, MA: University of Massachusetts Press.

Olson, K., Yang, V., Tadesse N., Chang Y., Yang N., \& Lee, S. (2003). Results of a farm and market survey for Hmong specialty crop farmers in the Minneapolis-St. Paul metro area. Staff Paper Series P03-11. Department of Applied Economics, University of Minnesota. Retrieved from http://agecon.lib.umn.edu

Ostrom, M. (2005a). Small Farms: The heart of Washington agriculture. Center for Sustaining Agriculture and Natural Resources Technical Report Series 2005-01-06, Washington State University.

Ostrom, M. (2005b). The importance of direct markets for Washington farmers. Center for Sustaining Agriculture and Natural Resources Research Brief Series 2005-03-08, Washington State University.

Ostrom, M. (2006). Everyday meanings of local food: Views from home and field. Journal of the Community Development Society, 37(1), 65-78.

Ostrom, M., \& Jackson-Smith, D. (2005). Defining a purpose: Agricultural extension, land grant research, and diverse farm constituencies. Journal of Sustainable Agriculture, 7(3), 57-76.

Ostrom, M., \& Jussaume, R. (2007). Assessing the significance of direct farmer-consumer linkages as a change strategy: Civic or opportunistic? In C. Hinrichs \& T. Lyson (Eds.), Remaking the North American food system (pp. 235-259). Lincoln, NE: University of Nebraska Press.

Ostrom, M., Jussaume R., \& Jarosz, L. (2002). Statewide random sample farmer mail survey with 1,166 respondents. Details at http://www.crs.wsu.edu/ outreach / rj/agsurvey/

Percy, R. (2005). The contribution of transformative learning theory to the practice of participatory research and extension: Theoretical reflections. Agriculture and Human Values, 22(2), 127-136.

Peters, S. J. (2002). Citizens developing a voice at the table: A story of educational organizing in contemporary Extension work. Journal of Extension, 40(4). Retrieved from http://www.joe.org/joe/ 2002august/al.php

Rheingold, H. (2008). Using participatory media and public voice to encourage civic engagement. In W. 
L. Bennett (Ed.), Civic life online: Learning how digital media can engage youth (pp. 97-118). The John D. and Catherine T. MacArthur Foundation Series on Digital Media and Learning. Cambridge, MA: The MIT Press.

Rhodes, M., \& Joseph, H. (2004). Immigrant and refugee farming programs and resources: A guide to projects, people, places, publications and other information. New Entry Sustainable Farming Project, Agriculture, Food and Environment Program, Tufts University, January.

Rural Roots, Inc. (2007a). Cultivating Success former student survey report. Prepared by Social Science Research Unit (SSRU), University of Idaho, Moscow, ID.

Rural Roots, Inc. (2007b). Cultivating Success: Surveying the needs of small farm producers in Idaho and W ashington report. Prepared by Social Science Research Unit (SSRU), University of Idaho, Moscow, ID.

Rural Roots, Inc. (2008). Cultivating Success course evaluation survey reports 2002-2008. University of Idaho, Moscow, ID.

Rural Roots, Inc. (2010). Cultivating Success former student survey of Latino and Hmong participants. Washington State University, Pullman, WA.

Stuart, D. (2008). Working paper and statistics on farmland in Washington. American Farmland Trust, October. Retrieved from http://www.farmland. org/programs/states/wa/WashingtonProject Update.asp
Suvedi, M., Knight Lapinski, M., \& Campo, S. (2000). Farmers' perspectives of Michigan State University Extension: Trends and lessons from 1996 and 1999. Journal of Extension 38(1).

Tufts University. (2010). New entry sustainable farming project. Retrieved from http://nesfp.nutrition. tufts.edu

United States Department of Agriculture (USDA). (1998). A time to act: A report of the USD A National Commission on Small Farms. MP-1545. Retrieved from http://www.csrees.usda.gov/nea/ag_systems/pdfs /time_to_act_1998.pdf

United States Department of Agriculture (USDA). (2007). Census of Agriculture. National Agricultural Statistics Service. Washington State and County Data. Retrieved from http://www.agcensus.usda. gov/Publications/2007/

Washington State Farmers Market Association (WSFMA). (2010). Data reported by individual markets and provided by WSFMA Coordinator, Jackie Aitcheson, at Annual WSFMA Meeting, Renton, WA, Jan. 28-30. 
Journal of Agriculture, Food Systems, and Community Development ISSN: 2152-0798 print / 2152-0801 online www.AgDevJournal.com 